\title{
ECOLOGICAL IMPACT OF CNG/GASOLINE BI-FUELLED VEHICLES
}

\author{
Ruslans Smigins \\ Latvia University of Agriculture \\ ruslans.smigins@1lu.lv
}

\begin{abstract}
The paper presents the results of an investigation carried on the potentiality of CNG as an alternative fuel for retrofitted gasoline engine analyzing its impact on exhaust gas emissions. In that case the results from emission testing of DACIA Logan on a chassis dynamometer MD-1750 are presented and discussed. The tests were realized at different testing conditions (idling, IM-240 cycle, 50 and $90 \mathrm{~km} \cdot \mathrm{h}^{-1}$ ) to see the influence on regulated and unregulated emissions. The analysis of the obtained experimental results has shown rapid increase of $\mathrm{HC}$ and $\mathrm{NO}_{\mathrm{x}}$ emissions and reduction of $\mathrm{CO}$ and $\mathrm{CO}_{2}$ emissions, when fuelled with $\mathrm{CNG}$ compared to gasoline.
\end{abstract}

Keywords: CNG, emissions, testing.

\section{Introduction}

Nowadays, the transport sector plays an important role in development of every country, but it also consumes significant amount of energy, being also the main source of environmental pollution. In the recent years, much more attention has been given to these problems, and new types of alternative fuels (bioethanol, biodiesel, etc.) are now offered. Some of these biofuels already occupy a definite share on the market, but it is still insufficient to overcome the problem of environmental pollution from transport and meet the EU Directives. Due to that now more attention is focused on three main energy sources for vehicles: electricity, hydrogen and natural gas promoting their development by the Directive 2014/94/EU, which requires the Member States to work on the development of a network of infrastructure allowing to use electricity, hydrogen and natural gas to powering the transport setting out minimum requirements for the building up infrastructure.

One of the most promising alternatives is compressed natural gas (CNG), which could meet the stringent emission regulations in the EU. The technology for natural gas usage is well developed and equipment could be successfully installed on the used passenger vehicles. Currently, most of the largest vehicle manufacturers offer methane fuelled vehicles with the factory installed CNG fuelling system. Among them, some companies offer installation of this system on different types of motor vehicles. In that case also upgraded biogas or biomethane has great perspectives as the main component of it as also natural gas is methane. Fuels containing methane as the base component are well known due to rapid use in power generation, home heating, and now also in transport. Methane represents few major advantages over the conventional liquid fuels - it is a cheap source of energy and it has positive impact on some pollutants when used as a motor fuel.These facts could be observed in case of new commercialy produced vehicles, but not always in case of retrofitted CNG vehicles. One of the first researchers [1] in case of retroffited $\mathrm{CNG}$ vehicles confirmed reduction of $\mathrm{CO}$ emissions by $53 \%$ and $\mathrm{CO}_{2}$ emissions by $20 \%$, but increase of $\mathrm{HC}$ and NOx emissions by $162 \%$ and $171 \%$, respectively. Besides that, the increase of the age of retrofitted CNG vehicle leaves an impact on the increase of emissions [1].

Many other researchers also have studied the impact of CNG, mainly focusing on the engine performance and gaseous emissions [1-4]. The results are different and could be affected by the vehicle model, age and effectiveness and the type of conversion kit. Putrasari [2] has realized research with Honda L15A spark ignition engine on W70 eddy current dynamometer with two CNG conversion kits (one - commercially produced; second - proposed conversion kit designed by the research centre) and has found that the lowest $\mathrm{HC}$ concentration at different throttle opening positions was using the standard gasoline fuel system (with some expectations), but the lowest $\mathrm{CO}$ concentration was using the standard gasoline fuel system and proposed CNG conversion kit based on the throttle opening position. Other research [3] shows results of a series of laboratory tests carried out in the emissions laboratory operating with Euro 5 bi-fuel light duty vehicle on gasoline and CNG using the multipoint injection gasoline fuel injection or natural gas injection system, depending on the fuel type in use. The researchers observed increase of $\mathrm{HC}$ and $\mathrm{CO}$ emissions, decrease of $\mathrm{CO}_{2}$ emissions for $\mathrm{CNG}$ compared to gasoline, as also strong difference in $\mathrm{CH} 4$ emissions for both fuels due to high levels of methane in the exhaust gas when running on CNG. Researchers [4] from China have examined the 
real-world emission characteristics of more than 20 light-duty $\mathrm{CNG}$ vehicles analyzing the driving cycle influence on the $\mathrm{CO}, \mathrm{CO}_{2}, \mathrm{HC}$ and $\mathrm{NO}_{\mathrm{x}}$ emissions. They have found that the $\mathrm{CO}_{2}, \mathrm{CO}$ and $\mathrm{HC}$ emission level emitted from the tested $\mathrm{CNG}$ vehicles under urban driving conditions was significantly greater than those under highway road conditions.

The objective of this study was to analyze the potential of emission reduction of retrofitted CNG light duty bi-fuelled vehicles, operating on gasoline and CNG. To achieve this goal an additional vehicle was tested on the chassis dynamometer in laboratory conditions monitoring and analyzing regulated and unregulated emissions.

\section{Materials and methods}

The impact of CNG on emissions and engine performance was tested on a retrofitted Dacia Loganvehicle for CNG/gasoline use. The engine was converted to a bi-fuel system from a gasoline engine and operated with either gasoline or CNG. Aspirated system kit was used for conversion of the vehicle for CNG use. The main engine specifications are listed in Table 1 and the schematic of the retrofitted experimental vehicle is shown in Fig. 1, reflecting the main components used in the conversion. The engine used in the tests is a four-cylinder, four stroke, water cooled, 9.5:1 compression ratio engine with industrial application. The tests were realized in the Alternative Fuel Research Laboratory of the Latvia University of Agriculture.

Table 1

Technical characteristics of the tested vehicle

\begin{tabular}{|l|c|}
\hline Parameter & Characteristics \\
\hline Name & Dacia Logan \\
\hline Production year & 2004 \\
\hline Engine capacity & $1390 \mathrm{~cm}^{3}$ \\
\hline Cylinder number and arrangement & 4, in line \\
\hline Compression ratio & 9.5 \\
\hline Maximum power & $55 \mathrm{~kW}$ at $5500 \mathrm{rpm}$ \\
\hline Maximum torque & $112 \mathrm{Nm}$ at $3000 \mathrm{rpm}$ \\
\hline
\end{tabular}

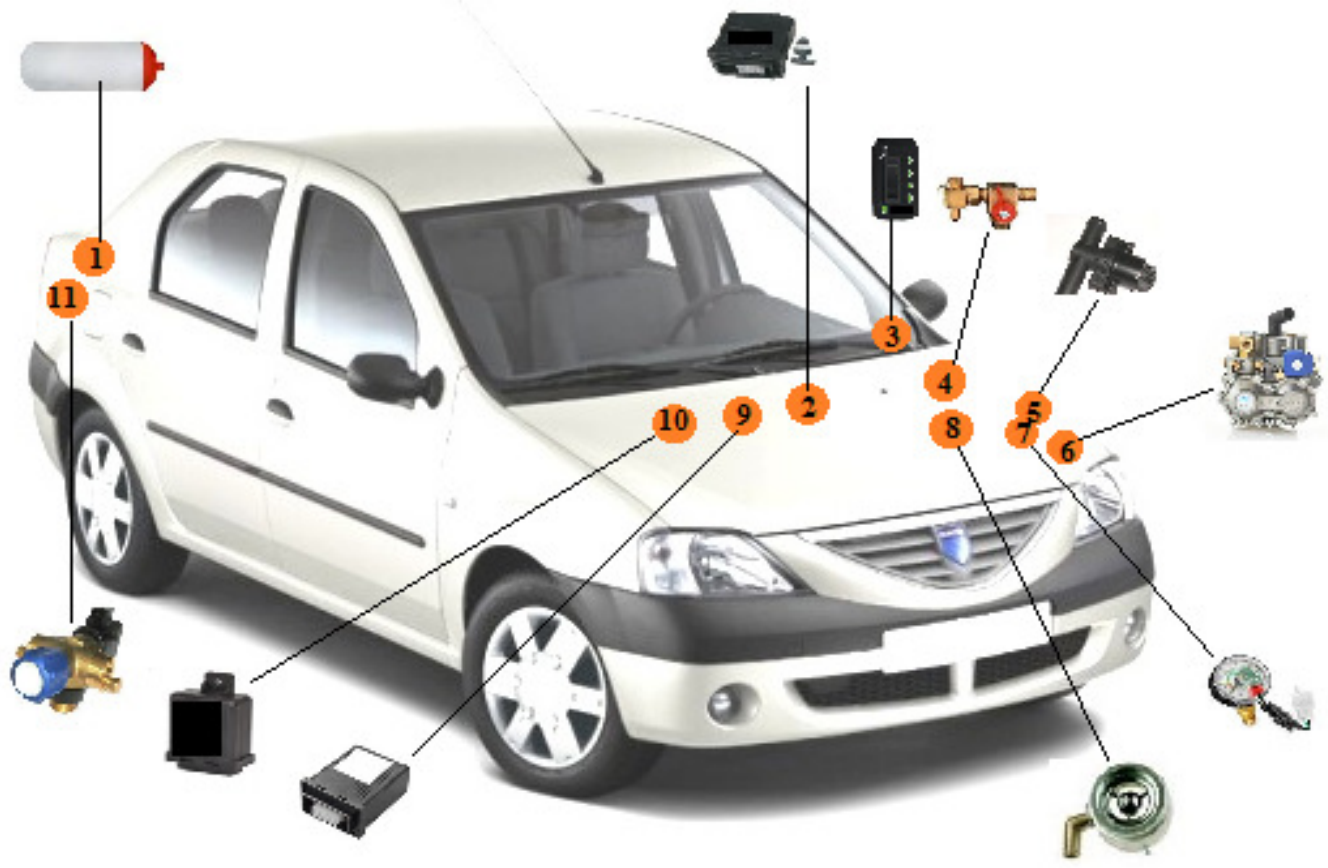

Fig. 1. Schematic of retrofitted CNG/gasoline bi-fuel vehicle: 1 - CNG cylinder; 2 - lambda feedback system; 3 - switch; 4 - filler valve; 5 - stepper motor; 6 - CNG reducer; 7 - pressure gauge; 8 - gas-air mixer; 9 - timing advance processor; 10 - emulator; 11 - cylinder valve 
The schematic diagram of the experimental setup used for studying the engine emission characteristics is shown in Fig. 2. One of the main pieces of equipment is the chassis dynamometer, which is used to apply a load to the test vehicle. During the tests a power curve was obtained, necessary for the engine power analysis for the mentioned fuels.

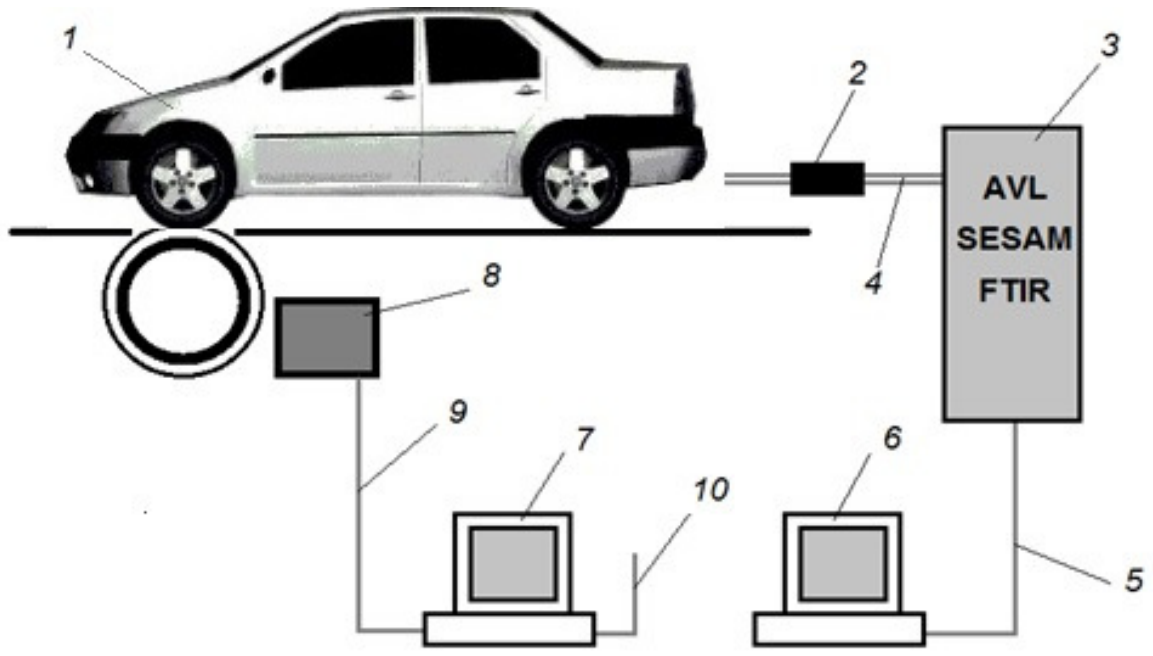

Fig. 2. Schematic diagram of the experimental setup: 1 - research object; 2 - heated filter; 3 - multicomponent exhaust gas measurement system AVL SESAM FTIR; 4 - heated gas line; 5 - AVL data communication cable; 6 - PC with special AVL software; 7 - Mustang chassis dyno control and data recording PC; 8 - power absorber unit; 9 - dyno date communication cable; 10 - screen communication cable

Emission tests were realized at idling, IM-240 cycle, 50 and $90 \mathrm{~km} \cdot \mathrm{h}^{-1}$. The choice of the last ones was done for the reason that it corresponds to the maximum allowed speed in Latvian urban and suburban areas. Constant speed measurements were performed for 2 minutes with the reading step of 1 second. Additionally a combined cycle IM-240 was realized, which simulates not only urban driving conditions, but also driving in non-urban area, with total duration of the test -240 seconds.

Emission measurements were realized by the AVL SESAM FTIR multicomponent exhaust gas measurement system, which allows to measure up to 25 gases simultaneously and some components can be calculated from this process. During the research all the gases were fixed, but more detailed analysis was done only for the most essential regulated exhaust gas components: nitrogen oxides $\left(\mathrm{NO}_{\mathrm{x}}\right)$, carbon monoxide $(\mathrm{CO})$, carbon dioxide $\left(\mathrm{CO}_{2}\right)$ and unburned hydrocarbons $(\mathrm{HC})$, as also unregulated exhaust gas components: ammonia $\left(\mathrm{NH}_{3}\right)$, methane $\left(\mathrm{CH}_{4}\right)$, acetylene $\left(\mathrm{C}_{2} \mathrm{H}_{2}\right)$ and ethane $\left(\mathrm{C}_{2} \mathrm{H}_{6}\right)$.

The drivability of the vehicle was unimpaired during the tests; the vehicle was tested with all the fuels in random order and each reading was repeated three times. The results of these three replications were averaged to decrease the uncertainty and reported.

The engine was operated on compressed natural gas (marked as CNG) and gasoline (marked as gasoline), meeting the EN 228:2004 standard.

\section{Results and discussion}

The experimental data, which characterize the variation of the engine dynamical and ecological factors using different fuels, can be seen in figures below. According to the test results, reduction in power using CNG can be seen, which could be explained by slower flame velocity and displacement of air by natural gas, which finally results in reduced $\mathrm{CNG}$ content due to the air volumetric efficiency and the charge energy density per injection [5]. This is a usually observed fact for CNG operation in engines designed for gasoline fuel use. In the current research it was observed that the average reduction in power for $\mathrm{CNG}$ was $24.85 \%$ compared to gasoline, but in the torque $-21.32 \%$ compared to gasoline (see Table 2). 
Engine power and torque using different fuels

Table 2

\begin{tabular}{|c|c|c|c|c|c|c|}
\hline & \multicolumn{3}{|c|}{ Torque, Nm } & \multicolumn{3}{c|}{ Power, kW } \\
\cline { 2 - 7 } & Gasoline & CNG & $\begin{array}{c}\text { Change } \\
(\%)\end{array}$ & Gasoline & CNG & $\begin{array}{c}\text { Change } \\
(\%)\end{array}$ \\
\hline $\begin{array}{c}\text { Minimal } \\
\text { values }\end{array}$ & 75.09 & 28.9 & -61.51 & 20.38 & 11.94 & -41.41 \\
\hline $\begin{array}{c}\text { Maximal } \\
\text { values }\end{array}$ & 101.49 & 89.04 & -12.27 & 41.53 & 31.01 & -25.33 \\
\hline $\begin{array}{c}\text { Average } \\
\text { values }\end{array}$ & 90.07 & 70.87 & -21.32 & 34.11 & 25.63 & -24.85 \\
\hline
\end{tabular}

Significant decrease in the engine power was observed in the engine speeds below $4000 \mathrm{rpm}$. Using the experimental values, part of which were presented in Table 2, a chart was drawn, where it is possible to see the full power and torque curves for the tested fuels (see Fig. 3).

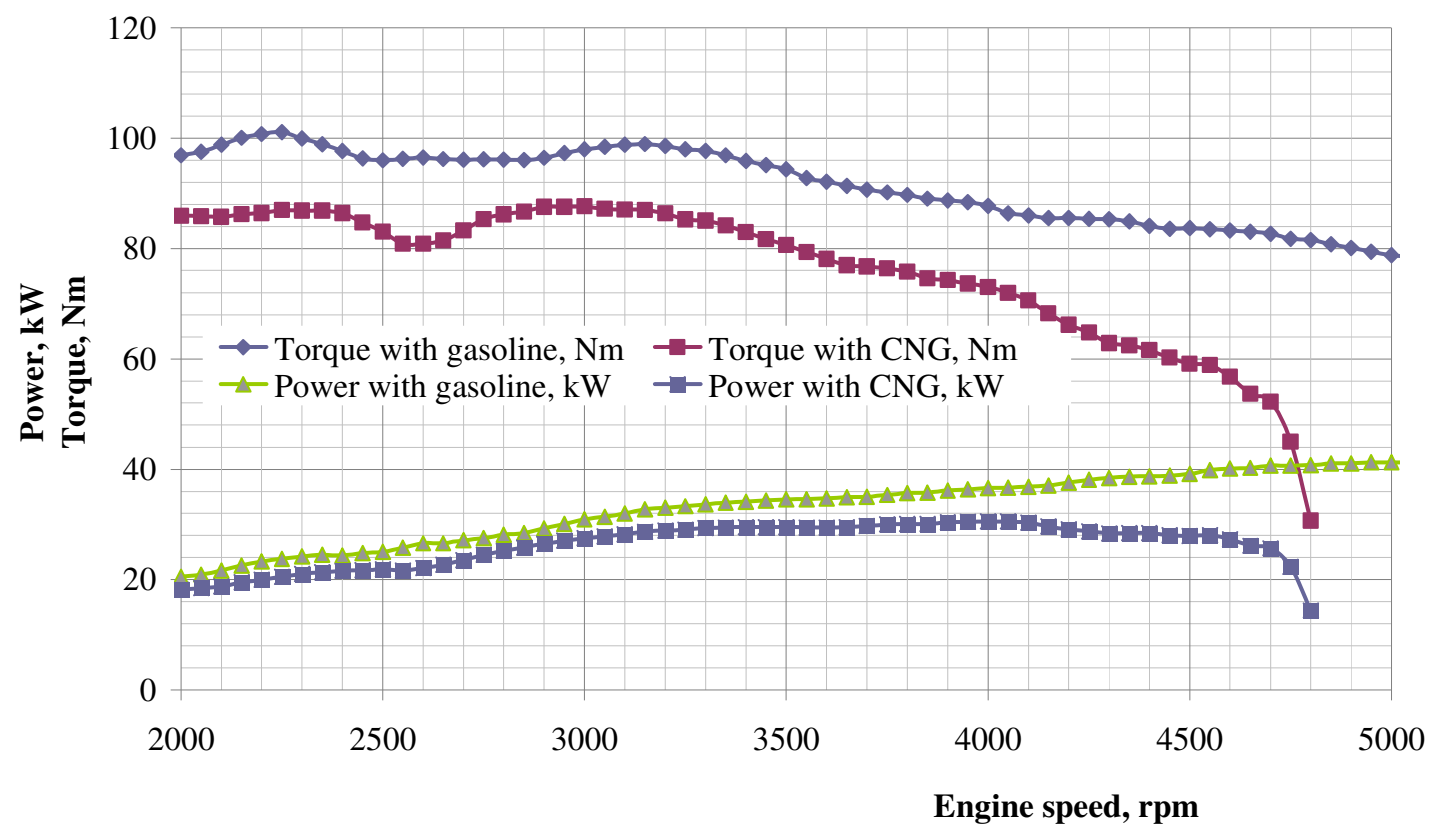

Fig. 3. Power and torque curves for different fuels

Positive effect of CNG use firstly could be observedaccording to $\mathrm{CO}$ and $\mathrm{CO}_{2}$ emission reduction - considerable decrease of $\mathrm{CO}$ and $\mathrm{CO}_{2}$ emissions were fixed in all testing conditions. The largest reduction of $\mathrm{CO}_{2}$ was observed in idling $(24.1 \%)$, but for $\mathrm{CO}$ the largest reduction was fixed at $50 \mathrm{~km} \cdot \mathrm{h}^{-1}(97.9 \%)$ than that for gasoline (see Fig. 4.). The largest values for $\mathrm{CO}_{2}$ were fixed at $90 \mathrm{~km} \cdot \mathrm{h}^{-1}$, but for CO - at the IM-240 cycle. Lower carbon emissions for CNG compared to gasoline could be explained by the fact that the hydrogen/carbon ratio of natural gas (4:1) is higher compared to gasoline (1.85:1) and therefore $1 \mathrm{MJ}$ of natural gas can produce by $17 \mathrm{~g} \mathrm{CO}_{2}$ smaller amount than that in gasoline use [6]. But it should be noted that higher $\mathrm{H}: \mathrm{C}$ composition not always guarantees reduced $\mathrm{CO}_{2}$ emissions [3].

Opposite situation was observed with $\mathrm{HC}$ and NOx emissions showing increase in all testing conditions for CNG compared to gasoline. The largest increase of $\mathrm{HC}$ was observed at $90 \mathrm{~km} \cdot \mathrm{h}^{-1}$, but the largest increase of NOx was fixed in idling using $\mathrm{CNG}$ compared with gasoline. The largest values for $\mathrm{HC}$ were fixed at the IM-240 cycle, but for $\mathrm{NO}_{\mathrm{x}}-$ at $50 \mathrm{~km} \cdot \mathrm{h}^{-1}$. Increase in NOx emissions in case of CNG could be explained by the fact that natural gas combustion is realized at higher temperature than that is in case of gasoline. Such process is possible due to a high adiabatic temperature of this gaseous fuel contributing to increased formation of nitrogen oxides. There could be the other factors leaving impact on the increase of NOx: the distribution of the hottest parts of the charge, thermal homogeneity and the timing of heat release [3].Increase in HC and NOx emissions for CNG fueled cars compared to gasoline ones was found also in other researches [7]. 

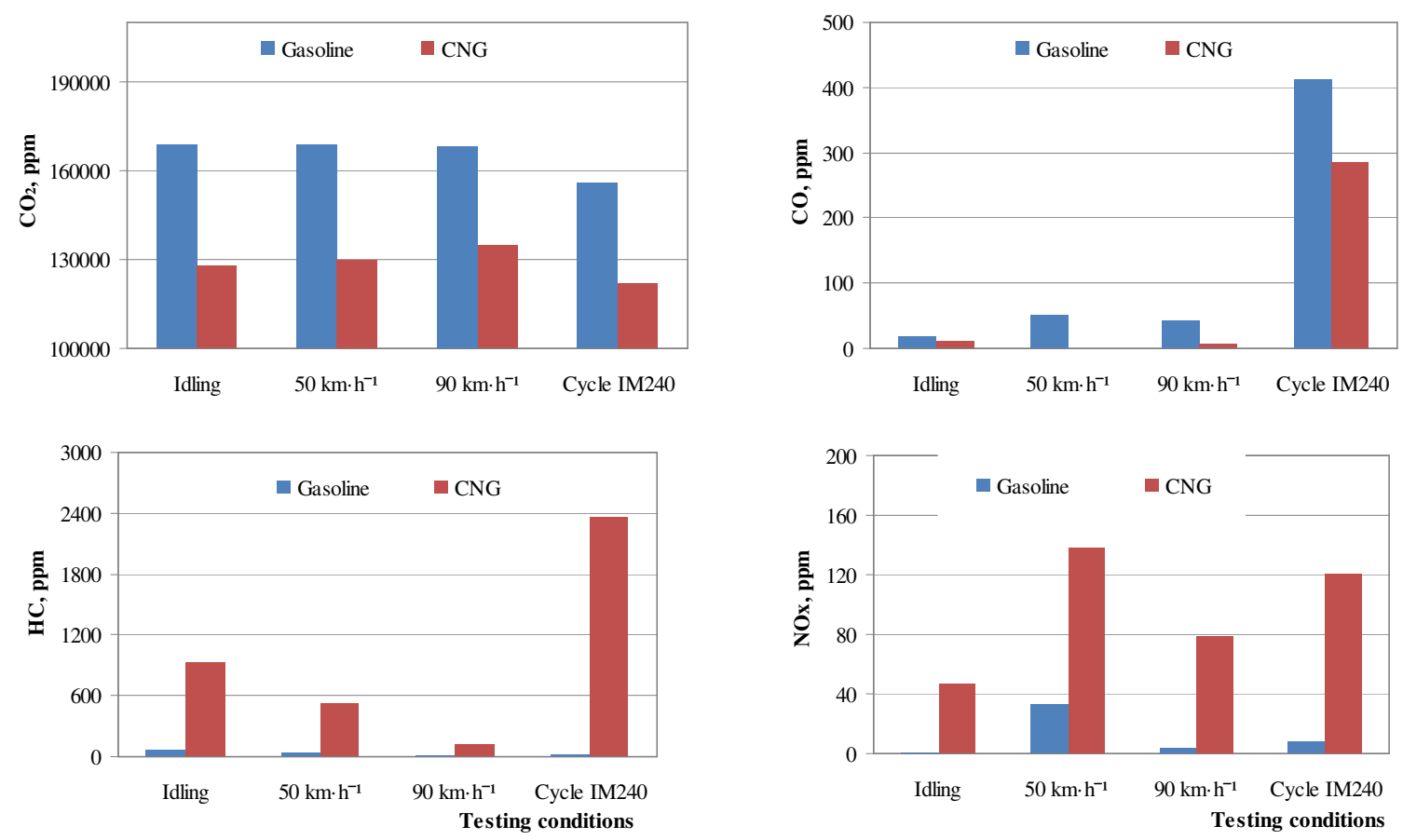

Fig. 4. Results of regulated emissions in different testing conditions
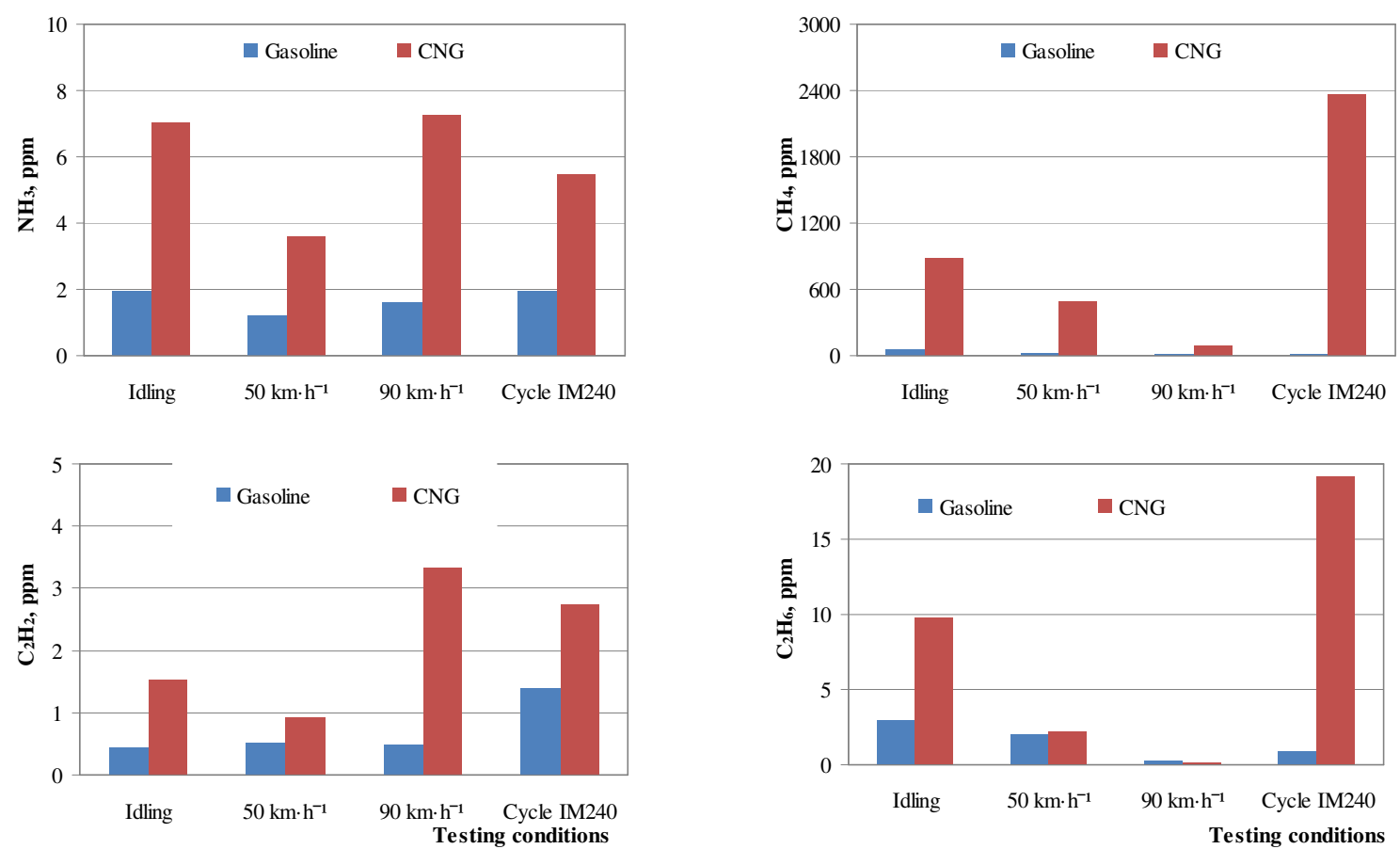

Fig. 5. Results of unregulated emissions in different testing conditions

The addition of $\mathrm{CNG}$ has not left a positive impact also to unregulated emissions, like ammonia $\left(\mathrm{NH}_{3}\right)$, methane $\left(\mathrm{CH}_{4}\right)$, acetylene $\left(\mathrm{C}_{2} \mathrm{H}_{2}\right)$ and ethane $\left(\mathrm{C}_{2} \mathrm{H}_{6}\right)$. Fig. 5 shows that all mentioned emissions increase with CNG compared to gasoline. It is not positive as ammonia is a toxic compound and a precursor in the formation of atmospheric secondary aerosols, classified under the European dangerous substances directive (67/548/EEC), and vehicles with internal combustion engines are considered as the main source of NH3 in the urban environment [8]. Other researchers [9] have found that $\mathrm{H}: \mathrm{C}$ ratio is partly responsible for ammonia emissions. If the values of ammonia and acetylene are not significant, then the values of methane are very large for CNG. Increase of methane in exhaust gases of CNG compared to gasoline is simply explainable by the fuel type used in the engine - non- 
methane emissions of $\mathrm{CNG}$ vehicles usually are lower, while methane emissions can be even ten times higher.

\section{Conclusions}

A number of conclusions can be done from the research, the main objective of which was to analyze emission and performance results of a retrofitted engine for the use of CNG and gasoline:

1. CNG usage in the retrofitted engine of light duty vehicle gives lower power and torque than gasoline throughout the speed range.

2. CNG usage in the retrofitted engine of light duty vehicle shows decrease of $\mathrm{CO}$ and $\mathrm{CO}_{2}$ emissions and increase of $\mathrm{HC}$ and $\mathrm{NOx}$ emissions in all testing conditions compared to gasoline.

3. CNG usage in the retrofitted engine of light duty vehicle shows increase of all fixed unregulated pollutants, like ammonia, methane, acetylene and ethane.

Totally, it should be noted that only certain exhaust components showed good results in the tests, which were done with one vehicle. Due to the results and lower price of fuel compared to gasoline, $\mathrm{CNG}$ could be considered as a potential fuel in retrofitted vehicles, but a closer look at the applied technology must be considered. Further testing with a larger number of vehicles is required for giving more detailed insight also in unregulated emissions, which could be important in case of future legislation limits.

\section{References}

1. Dondero L. and Goldemberg J. Environmental implications of converting light gas vehicles: the Brazilian experience. Energ. Policy, vol. 33, 2005, pp. 1703-1708.

2. Putrasari Y., Preptijanto A., Nur A., Wahono B., Santoso W.B. Evaluation of performance and emission of SI engine fuelled with CNG at low and high load condition. 2nd International Conference on Sustainable Energy Engineering and Application, Energy Procedia, vol. 68, 2015, pp. 147-156.

3. Bielaczyc P., Woodburn J., Szczotka A. An assessment of regulated emissions and CO2 emissions from a European light-duty CNG-fueled vehicle in the context of Euro 6 emissions regulations. Applied Energy, vol. 117, 2014, pp. 134-141.

4. Yao Z., Cao X., Shen X., Zhang Y., Wang X., He K. On-road emission characteristics of CNGfueled bi-fuel taxis. Atmospheric Environment, vol. 94, 2014, pp. 198-204.

5. Jahirul M.I., Masjuki H.H., Saidur R., Kalam M.A., Jayed M.H., Wazed M.A. Comparative engine performance and emission analysis of CNG and gasoline in a retrofitted car engine. Applied Thermal Engineering, vol. 30, 2010. pp. 2219-2226.

6. Gaudio, R., Volpoi, E. Natural Gas and CO2-Natural Gas Is a Champion in Road Transport and Also Saving CO2 Emissions. A Position Paper of NGVA Europe, 2009.

7. Xie, S.X., Hu, J.N., Bao, X.F., Li, Z.H., Wang, H.T., Zhang, K.S., 2011. Real-world emission characteristics of natural gas-gasoline bi-fuel vehicles. Acta Sci. Circumst., vol.31 (11), pp. 2347-2353.

8. Suarez-Bertoa R., Zardini A.A., Astorga C. Ammonia exhaust emissions from spark ignition vehicles over the New European Driving Cycle. Atmospheric Environment, vol. 97, 2014, pp. 43-53.

9. Bielaczyc P, Szczotka A, Swiatek A, Woodburn J. A comparison of ammonia emission factors from light-duty vehicles operating on gasoline, liquefied petroleum gas (LPG) and compressed natural gas (CNG). SAE Int J Fuels Lubricants 2012, vol. 5(2), pp. 751-759. http://dx.doi.org/10.4271/2012-01-1095. 